\title{
Nocturnal variation of the zooplankton community in coral reef substrates at Isla del Coco National Park (Eastern Tropical Pacific)
}

\author{
Octavio Esquivel-Garrote ${ }^{1,2 *}$ \& Álvaro Morales-Ramírez ${ }^{1,3}$ \\ 1. Escuela de Biología, Universidad de Costa Rica, San José, Costa Rica. \\ 2. Laboratório de Zooplâncton, Instituto de Oceanografia, Universidade Federal de Rio Grande, Rio Grande, RS, Brasil; \\ octageo@gmail.com \\ 3. Centro de Investigación en Ciencias del Mar y Limnología, Universidad de Costa Rica, San José, Costa Rica; \\ alvaro.morales@ucr.ac.cr \\ * Correspondence
}

Received 31-I-2019. Corrected 05-V-2019. Accepted 30-VII-2019.

\begin{abstract}
Introduction: Zooplankton is a major link in coral reef food webs and a source of nutrients for corals. Demersal zooplankton in coral reefs makes diel migrations at night to avoid predation by fish and corals, increasing abundance and biomass at night. Objectives: To study the composition and variation of the demersal and pelagic zooplankton community at night and to increase the taxonomic knowledge of the benthic copepod fauna over different substrates of a coral reef. Methods: Traps made of plastic, with a $100 \mu \mathrm{m}$ mesh size collector cup attached, were placed for 12 hours between 5-10 m depth over four substrates: (1) sand, (2) small and (3) big colonies of Porites lobata, and (4) dead and alive corals. Sampling started at dusk (1800 h), and the collector cups were collected and replaced at 2100 and 0000, and the last samples removed at down $(0600 \mathrm{~h})$. Results: The highest abundance of zooplankton was capture over P. lobata colonies between 0000 to $0600 \mathrm{~h}$. Copepods (adults, copepodites, and nauplii) dominated the community structure and were more abundant during all the time intervals and substrates. Pelagic copepods were more abundant than the benthic, however, not more diverse. Among the benthic copepods, 20 new records of harpacticoids and calanoids were registered for Isla del Coco and Costa Rican waters. Appendicularians and decapod larvae were also abundant. Changes in coral reef community structure were related with time and not with the kind of substrate, although some taxa were found only in a specific time interval or substrate. Conclusions: Community structure and abundance of demersal and pelagic coral reef zooplankton in Chatham Bay were dominated by copepods, larvaceans and decapod larvae, similar to other coral reefs around the world. The highest abundance peak of organisms in the water column between 0000 to $0600 \mathrm{~h}$ could be related to diel migration.
\end{abstract}

Key words: migration; demersal; traps; abundance; Isla del Coco.

Esquivel-Garrote, O., \& Morales-Ramírez, A. (2020). Nocturnal variation of the zooplankton community in coral reef substrates at Isla del Coco National Park (Eastern Tropical Pacific). Revista de Biología Tropical, 68(Suppl. 1), S261-S270.

Coral reef ecosystems grow in relatively poor waters, however, are areas of high productivity and abundance of organisms. Within the coral reef ecosystem, there is a tight recycling of nutrients and a self-generated food web (Porter \& Porter, 1977). Zooplankton is a major link in the food webs of coral reefs (Alldrege \&
King, 2009) and a key source of allochthonous nutrients for the corals (Yahel, Yahel, \& Genin, 2005a). The coral reef zooplankton is represented by complex assemblies from different sources: resident species, demersal migratory species, holozooplankton species from oceanic waters transported onto the reef, and reef 
merozooplankton species (Heidelberg, Sebens, \& Purcell, 2004). This complex diversity provides substantial nutrient inputs for coral reef fishes, corals and other predators (Heidelberg, O'neil, Bythell, \& Sebens, 2010), bringing inorganic nutrients and vitamins which cannot be obtained by the corals through zooxanthellae photosynthesis (Sebens, 1987).

The diel migration patterns of the coral reef zooplankton are known to increase both the biomass and abundance at night, thus becoming an important energy source for plankton feeders like corals (Nakajima, Yoshida, Othman, \& Toda, 2008; Nakajima, Yoshida, Othman, \& Toda, 2009). Nocturnal migration in coral reefs is considered as a mechanism to avoid the high predation that occurs near the bottom by zooplanktivores such as corals (Sebens, Grace, Helmuth, Maney, \& Miles, 1998), and is suggested that these migrations are one of the major causes shaping the temporal variations of community structure and abundances of zooplankton over coral reefs (Yahel, Yahel, Berman, Jaffe, \& Genin, 2005b).

Characterize the community structure over coral reef surfaces could be a challenging task, due to the artifacts of different sampling strategies, topographically complex structures and changes in zooplankton composition due to diel migration (Heidelberg et al., 2010). One of the first attempts to quantify, describe and register the diel migration of the zooplankton community over coral reefs was made by Emery (1968) in the Florida Keys, using nets and a suction device at different times of the day, nineteen taxonomic groups were identified, being copepods the most abundant. Alldredge and King (1977), using emergence traps placed over different substrates, quantified demersal zooplankton at Lizard Lagoon in the Great Barrier Reef. They found a significant preference of substrate by demersal zooplankton and a distinct pattern of nocturnal vertical migration. More recent studies using traps and other devices have recorded the diel migration pattern over coral reefs (Yahel et al. 2005b; Nakajima et al. 2008; Alldredge \& King, 2009; Nakajima et al. 2009), registering zooplankton abundance peaks at dusk. Recently, AndradiBrown et al. (2017) compared shallow and mesophotic zooplankton communities at Utila island in the Mesoamerican Barrier Reef, and Smith, Richter, Fabricius, and Cornils (2019) described the substrates preferences and migration behavior of Labidocera spp. in two coral reefs systems in Papua New Guinea. Despite these efforts characterizing the community structure of zooplankton over coral reefs substrates, information about reef-associated demersal and pelagic zooplankton in oceanic islands is very scared. Several zooplankton studies at Isla del Coco have described different taxonomic groups (Jiménez-Cueto, Suárez-Morales, \& Morales-Ramírez, 2012; Gasca \& Morales-Ramírez, 2012; Castellanos, Hernández, Morales-Ramírez, \& Corrales, 2012), new species (Suárez-Morales \& Morales-Ramírez, 2009; Suárez-Morales \& Gasca, 2012; Esquivel-Garrote, SuárezMorales, \& Morales-Ramírez, 2015) and the zooplankton community (Morales-Ramirez, 2008); however, no studies have been made to characterize the zooplankton community over coral reef substrates.

Due to lack of information about zooplankton associated to different coral reef substrates in oceanic islands, the objectives of this study were to characterize the community structure of the zooplankton associated to different coral reefs substrates, to establish the nocturnal variation of the zooplankton community according to substrate type or/and sampling hour and to increase the knowledge of the benthic copepod fauna over different substrates in a coral reef system in Chatham Bay at Isla del Coco National Park, an oceanic island in the Eastern Tropical Pacific.

\section{MATERIALS AND METHODS}

Study site: Isla del Coco is an oceanic island located $530 \mathrm{~km}$ south-west from the Pacific coast of Costa Rica, in the Eastern Tropical Pacific (ETP) $\left(5^{\circ} 32^{\prime} \mathrm{N}-87^{\circ} 04^{\prime} \mathrm{W}\right)$. It has $24 \mathrm{~km}^{2}$ of land and $1997 \mathrm{~km}^{2}$ of marine surface. In 1978 it was declared a National Park 
and UNESCO deemed it as a Human Heritage Site in 1997 (Cortés, 2008). The island is influenced by the North Equatorial Countercurrent (NECC), with a seasonal variation in its intensity (Lizano, 2008). The west-east flow carries water and plankton from the central Pacific Ocean to the American coast; thus, Isla del Coco is primarily affected by the NECC and is the first point for species establishment and distribution in the ETP (Cortés, 2008). Samples were collected in a coral reef located in Chatham Bay (Fig. 1), characterized by a high degree of rugosity and covered mainly by sand. Coral cover is moderate and dominated by Porites lobata, and there is low coverage of crustose calcareous algae (Alvarado et al., 2016).

Sampling: The sampling was conducted during the night of July 3, and the dawn of July 4, 2011. One zooplankton trap was placed over four different kinds of substrates (5-10 $\mathrm{m}$ deep): big P. lobata colonies (BPC), small $P$. lobata colonies (SPC), dead and live coral
(DaAC, different from P. lobata), and sand. The traps consisted of a cone made with plastic bags, and a collector cup (mesh size: $100 \mu \mathrm{m}$ ) attached at the end of the aperture; chains were used at the base of the traps to fix them to the substrate (Fig. 2). The traps were placed at $1800 \mathrm{~h}$ and the collector cups were collected at 2100, 0000 and $0600 \mathrm{~h}$. Samples were fixed using $4 \%$ formaldehyde. A total of 12 samples were collected, one per each time interval, over the four different substrates. The samples were analyzed at the Zooplankton Laboratory (CIMAR, UCR). The total of organisms per sample was counted and identified to the minimum taxonomical possible level, focusing mainly on the species-level identification of copepods. The amount of individuals was expressed as abundance.

Statistical analysis: Total abundances of zooplankton were transformed using $\log$ $\mathrm{X}+1$. An ANOSIM was conducted to test similarities of zooplankton composition among substrates and sampling time intervals.

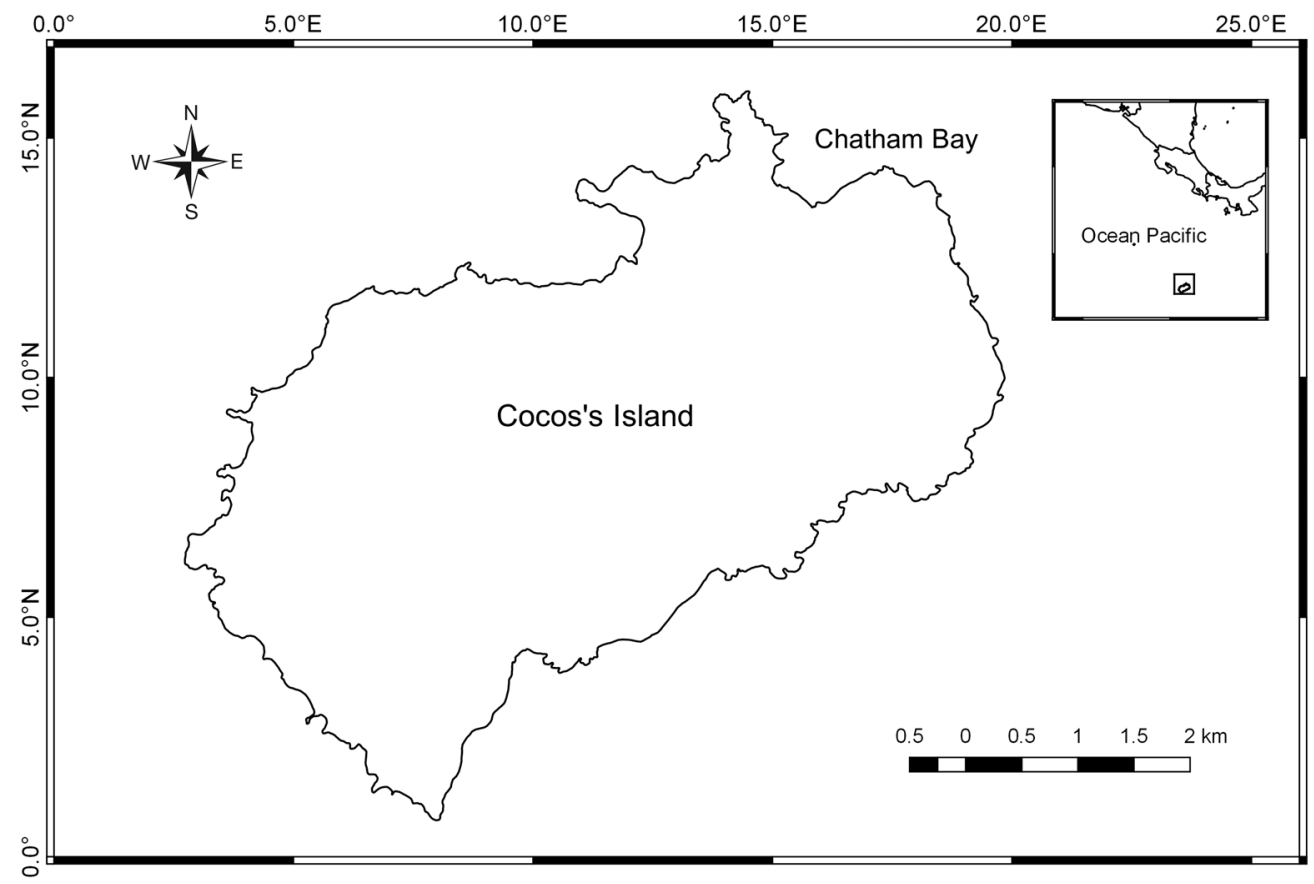

Fig. 1. Location of Chatham Bay coral reef at Isla del Coco National Park. 
A SIMPER test was used to determine the contribution of each taxon to dissimilarities in the community structure.

\section{RESULTS}

A total of 5049 individuals were counted from 22 different taxonomic groups, corresponding to 90 taxa (i.e. putative species). The copepods were the dominant group in all samples. Twenty new records of families, genera, and species of benthic copepods were found for Costa Rican waters: one genus of the family Cyclopinidae and Clausidiidae (Order Cyclopoida), and seven families, eight genera and ten species within the Order Harpacticoida (Table 1). Fifty-three copepod species were identified, the order Harpacticoida was the richest with 20 species ( $\mathrm{n}=706$ individuals; 76

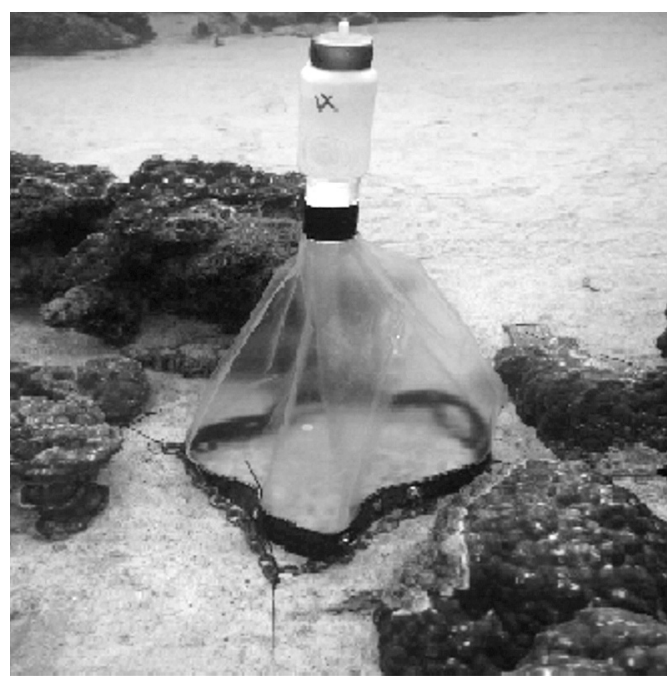

Fig. 2. Zooplankton traps used to collect samples in different substrates and different time intervals at Isla del Coco, during July 2011. Photo: By Jaime Nivia.

TABLE 1

List of benthic copepods collected in traps place in different substrates of a coral reef (5-10 m depth) in Isla del Coco National Park, Costa Rica

\begin{tabular}{|c|c|c|c|}
\hline Order & Family & Genera & Specie \\
\hline \multirow[t]{2}{*}{ Cyclopoida } & Clausidiidae & Hyphalion** & sp. \\
\hline & Cyclopinidae* & Cyclopuella** & $\mathrm{sp}$ \\
\hline \multirow[t]{18}{*}{ Harpacticoida } & Ameiridae* & indet. & sp. \\
\hline & Dactylopusidae* & Dactylopodopsis cf. & dilatata*** \\
\hline & & Dactylopusia** & sp.1 \\
\hline & & Dactylopusia** & sp.2 \\
\hline & Harpacticidae & Harpacticus cf. & obscurus $* * *$ \\
\hline & & Mucropedia** & sp. \\
\hline & Idyanthidae* & Idyellopsis cf. & typica*** \\
\hline & Laophontopsidae* & Aculeopsis cf. & longisetosa $* * *$ \\
\hline & Miracidae & Teissierella cf. & salamboi*** \\
\hline & Parastenheliidae* & Parastenhelia** & sp. \\
\hline & Peltidiidae & Alteuthella** & sp. \\
\hline & Peltidiidae & Parapeltidium $* *$ & $\mathrm{sp}$ \\
\hline & Porcellidiidae* & Porcellidium cf. & yoroium $* * *$ \\
\hline & Thalestridae & Eudactylopus cf. & krusadensis $* * *$ \\
\hline & & & lucayosi*** \\
\hline & & Eudactylopus** & sp. \\
\hline & & Parathalestris cf. & incerta*** \\
\hline & Tisbidae* & Tisbe ${ }^{* *}$ & sp. \\
\hline
\end{tabular}

*New family record, ** new genera record, *** new species record for Costa Rica and Isla del Coco. 
TABLE 2

Relative abundance of each taxonomic group of coral reef zooplankton during different time intervals between dusk and dawn, Chattam Bay, Isla del Coco National Park

\begin{tabular}{|c|c|c|c|c|}
\hline Taxa/Time interval & $1800-2100$ & $2100-0000$ & $0000-0600$ & Total abundance \\
\hline Adult copepods & 23,9 & 27,6 & 49,7 & 37,9 \\
\hline Nauplii & 50,1 & 45,2 & 35,1 & 41,6 \\
\hline Copepodite & 5,0 & 15,4 & 7,1 & 8,1 \\
\hline Appendicularia & 4,6 & 5,7 & 2,6 & 3,9 \\
\hline Isopoda & 1,0 & 1,9 & 1,6 & 2,1 \\
\hline Amphipoda & 0,2 & 2,3 & 1,1 & 1,5 \\
\hline Polychaeta & 0,5 & 0,2 & 0,6 & 1,5 \\
\hline Mysidacea & 1,3 & 0,8 & 0,4 & 1,2 \\
\hline Chaetognatha & 0,1 & 0,2 & 0,4 & 0,8 \\
\hline larva decápodo & 7,1 & 0,3 & 0,3 & 0,5 \\
\hline Tanaidacea & 0,3 & 0,1 & 0,2 & 0,2 \\
\hline Pteropoda & 0,0 & 0,0 & 0,2 & 0,2 \\
\hline Ictioplancton & 0,0 & 0,0 & 0,1 & 0,1 \\
\hline Heteropoda & 5,6 & 0,0 & 0,1 & 0,1 \\
\hline Stomatopoda & 0,1 & 0,0 & 0,1 & 0,1 \\
\hline Euphausiacea & 0,0 & 0,1 & 0,1 & 0,1 \\
\hline Cipridina & 0,2 & 0,0 & 0,1 & 0,1 \\
\hline Salpida & 0,0 & 0,0 & 0,0 & 0,1 \\
\hline Ostracoda & 0,0 & 0,0 & 0,0 & 0,0 \\
\hline Cnidaria & 0,2 & 0,0 & 0,0 & 0,0 \\
\hline Doliolida & 0,0 & 0,1 & 0,0 & 0,0 \\
\hline Cephalopoda & 0,0 & 0,1 & 0,0 & 0,0 \\
\hline Total \% & 100 & 100 & 100 & 100 \\
\hline
\end{tabular}

benthic, 630 planktic), then Calanoida with 14 species $(\mathrm{n}=280)$, and Cyclopoida (8 spp., $\mathrm{n}=482$ ). Planktic copepods were most abundant. The harpacticoid Microsetella rosea was the most abundant copepod species (32\%), followed by Siphonostomatoida and the cyclopoids Oncaea spp., which reached 23\% and $14 \%$ of the total abundance, respectively.

Copepods nauplii (42\%) and adult copepods $(38 \%)$ were the most dominant taxa in all time intervals, while appendicularians and decapod larvae were the most abundant taxa following copepods ( $4 \%$ and $2 \%$, respectively) (Table 2). The abundance between time intervals showed dissimilarities among community composition (ANOSIM, $\mathrm{R}=33.60 \%, \mathrm{p}=0.003$ ). Adult copepods were abundant in every substrate except in $P$. lobata colonies between $0000 \mathrm{~h}$ and $0600 \mathrm{~h}$, and nauplii reached higher abundances from 1800 to $2100 \mathrm{~h}$. Copepodites were more abundant from 2100 to $0000 \mathrm{~h}$ in small P. lobata colonies (Fig. 2F), and decapod larvae from 1800-2100 over the sand patches. Pterotracheoidea were more abundant in small and big P. lobata colonies and in dead and live corals between 1800 and $2100 \mathrm{~h}$. The highest amount of individuals was recorded between 0000 and $0600 \mathrm{~h}$ in every substrate (Fig. 3).

Benthic copepods (harpacticoids, and cyclopoids), were more diverse from 0000 to $0600 \mathrm{~h}$, comprising 18 taxa. However, the highest amount of individuals was registered between 1800-2100 h. The benthic harpacticoids were the most abundant in each time of sampling. Copepods showed a variation in abundance among time intervals, Microsetella rosea was the most abundant in every substrate between 0000-0600 h (Fig. 4A, Fig. 4C, Fig. $4 \mathrm{E}$ ), except in dead and alive corals where Siphonostomatoida were more abundant (Fig. 


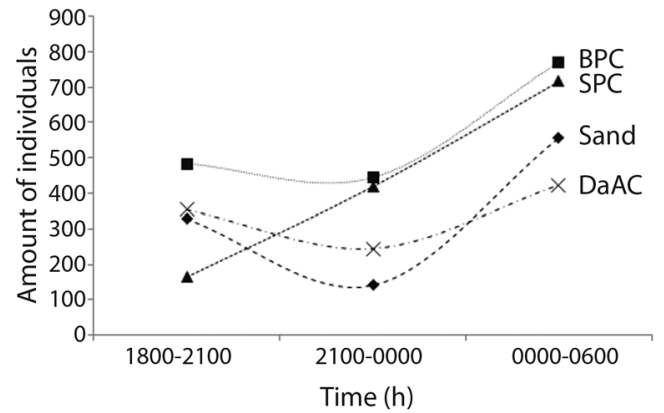

Fig. 3. Abundance of zooplankton $(\mathrm{N}=5049)$ in the traps at different time intervals per substrate: big $P$. lobata colonies (BPC); small P. lobata colonies (SPC); dead and other alive corals (DaAC), and sand.

4G); Paracalanus aculeatus also showed higher abundances between 0000-0600 h (Fig. 4B, Fig. 4D, Fig. 4H), while individuals of Siphonostomatoida were present in every substrate with the highest abundances registered from 0000 to 0600 h (Fig. 4A, Fig. 4C, Fig. 4F, Fig. $4 \mathrm{G})$. In general, the higher relative abundance (48\%) was recorded from 0000 to $0600 \mathrm{~h}$.

The SIMPER analysis revealed which taxa made the higher contribution for differences in community structure between different time intervals. Siphonostomatoida Order was more abundant from 0000 to $0600 \mathrm{~h}$ and contributed with $5 \%$ of the dissimilarities, Pterotracheoidea also contributed 5\% and were only present from 0000 to $0600 \mathrm{~h}$. Other important groups, each contributing with $4 \%$ to the total difference, were the decapod larvae, recorded from 1800 to $0000 \mathrm{~h}$; M. rosea, found at any time but with higher abundances from 0000 to $0600 \mathrm{~h}$, and amphipods, relatively constant between intervals.

Among other taxa, copepods of the family Clausidiidae, Cyclopoidae, Miracidae, the species Lucicutia flavicornis, Oithona plumifera, and also fish larvae, megalopas, Mysis shrimps, and copepodites, were only present between 0000 to $0600 \mathrm{~h}$. Luciferidae, benthic copepods like Aculeopsis spp., Alteuthella spp., and Monstrillopsis chathamensis were found from 1800 to $2100 \mathrm{~h}$. Others, like Undinula vulgaris and Parathalestris incerta, were only present from 2100 to $0000 \mathrm{~h}$.
The sampled zooplankton communities did not show differences among the substrates (ANOSIM, $\mathrm{R}=8.60 \%, \mathrm{p}=0.719$ ). Although, the major amount of organisms were captured over big and small P. lobata colonies. Also, it was observed that some organisms were captured in just one kind of substrate, i.e. harpacticoids of the families Ameiridae and Miracidae, cyclopoids of the family Clausidiidae, the species Lucicutia flavicornis, Eudactylopus lucayosi and Oithona plumifera, and fish larvae, were found above sand. Others, as copepods of the Cyclopinidae family, the species Parapeltidium sp., Porcellidium cf. yoroium, decapod larvae (Porcellanidae), Pterotracheiodea, Phyllosoma larvae and Ostracoda, were found above the big colonies of P. lobata. On the other hand, Parathalestris cf. incerta, Dactylopodopsis cf. dilatata, Tisbe sp., Harpacticus cf. obscurus, Hyphalion sp., Idyellopsis cf. typica, and Monstrillopsis chathamensis, were found above small colonies of P. lobata. The copepods Mucropedia sp., Aculeopsis cf. longisetosa, Alteuthella sp., Dactylopusia sp. 1, Dactylopusia sp. 2, Eudactylopus cf. krusadensis and decapod larvae of Luciferidae family were found just in dead and alive coral.

\section{DISCUSSION}

This study presents the nocturnal variation of zooplankton community structure over different substrates in a coral reef system in Chatham Bay at Isla Coco. The composition structure of demersal and pelagic zooplankton found in this study, constituted mainly by copepods, appendicularians, isopods, amphipods, polychaetes, mysids, shrimps and larval forms, coincides with the taxa stated by Porter \& Porter (1977) as the one that lives in the crevices of the reef by day and migrate into the water column at night.

In this study were registered 20 species of benthic copepods which are new records, increasing from 29 to 49 species the list of benthic copepods already reported for Costa Rican waters (Morales-Ramírez, Suaréz-Morales, Corrales-Ugalde, \& Esquivel-Garrote, 2014). 


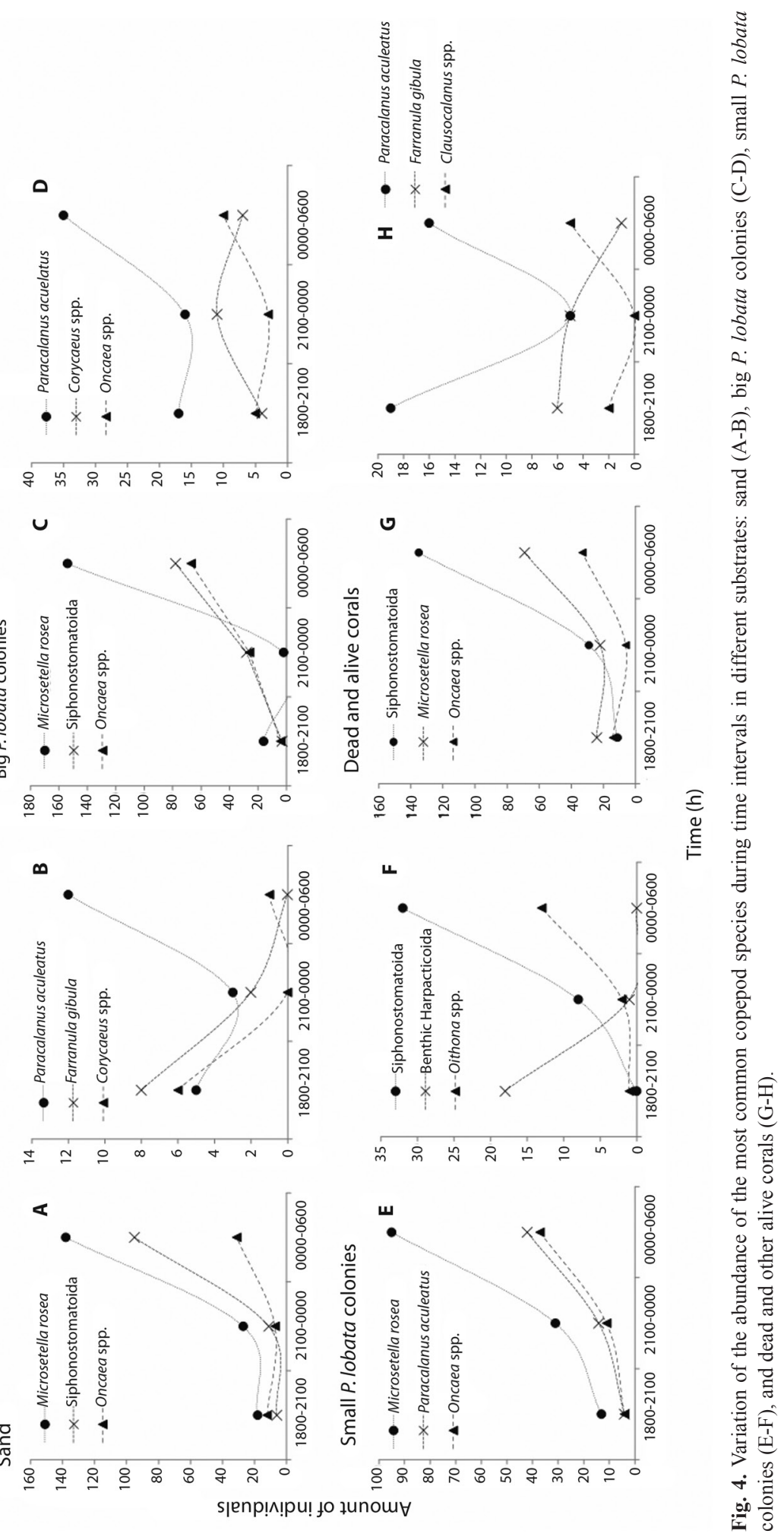


Taking into account the role of islands as centers of species distribution and as places with a higher level of endemism (Briggs, 1966; Kier et al., 2009), it is to be expected that in Isla de Coco new records and new species can still be found. During the last decade, four new species of pelagic copepods have been recorded for Isla del Coco (Suárez-Morales \& Morales-Ramírez, 2011; Suárez-Morales \& Gasca, 2012; EsquivelGarrote, Suárez-Morales, \& Morales-Ramírez, 2015). There is little information about benthic copepods of Isla del Coco (Morales-Ramírez, et al. 2014), despite the existence of several studies about the benthic fauna: sipunculids and echiurans had been reported (Dean, SibajaCordero, Cortés, Vargas, \& Kawauchi, 2010), benthic polychaeta (Dean, Sibaja-Cordero, \& Cortés, 2012), one amphioxus (Sibaja-Cordero, Trocoso \& Cortés, 2012). Also, Sibaja-Cordero et al. (2016) reported some families of benthic copepods from the sandy bottoms of the island.

The most abundant organisms in this study were copepods, including nauplii, copepodites and adults. Similar results were found by Nakajima, Yoshida, Othman, and Toda (2008) in a coral reef in Redang Island, Malaysia. In this study they found copepod nauplii as the most abundant taxa and responsible for the diel migration pattern observed, where the peak of abundance was from 1800 to $2100 \mathrm{~h}$, as was recorded in this study. Other studies had registered similar findings in other coral reefs, like in Tioman island, Malaysia and Conch Reef, Florida, where nauplii and copepods got the highest abundances and at night (Nakajima et al., 2009; Heidelberg et al., 2010). Higher abundances of copepods (adults, nauplii and copepodites) at night could be related to diel migration due to day time zooplanktivory by fish, which might be one of the major factors determining the diel migration pattern in coral reef zooplankton (Hamner, Jones, \& Carleton, 1988; Hobson, 1991).

The community structure of demersal zooplankton was more influenced by time than by the kind of substrate. In the Red Sea, differences in community composition were found while collecting zooplankton at day and night over different substrates, the differences observed were related with the time and not with the substrate (Yahel et al., 2005b). Jacoby and Greenwood (1988) also registered those differences in the planktic-benthic composition after observed migration peaks at different hours, either day or night, of different taxa like copepods (nauplii, copepodites and adult), chaetognaths, appendicularians, tanaidaceans, decapod larvae, and others. On the other hand, Olhorst (1982) stated that migration does not occur in just one pulse, and takes place at different times along the night time. However, several authors coincided that the major migration pulse happens at dusk after $1800 \mathrm{~h}$ (Alldredge \& King, 1977; Olhorst, 1982; Walters \& Bell, 1986; Yahel et al., 2005b).

Although we did not find differences among substrates, some organisms were found associated with one kind of particular substrate. According to Alldredge and Kind (1977), some organisms can keep certain positions in specific areas of the reef. Several strategies might explain this behavior: A) through active swimming; B) using crevices, caves, and coral heads as protection from predators and currents, and C) residing close to the bottom (Emery, 1968). These no significant differences between substrates could be explained because during migration, once emerged to the water column, zooplankton can be dispersed and quickly colonize a new substrate (Jacoby \& Greenwood, 1988). The higher abundance of individuals found over corals could be explained by the fact that those formations give protection against physic forces and might increase the availability of food, like mucus or bacteria, which could improve the survival of demersal zooplankton on this habitat (Jacoby \& Greenwood, 1988).

In conclusion, the composition and abundance of coral reef zooplankton in Isla del Coco is influenced by the diel migration pattern and not by the substrate, and this composition is similar to other coral reef systems around de world. The identification of new records or new species emphasizes the importance of Isla del Coco as a hot spot of marine biodiversity. 
However, it is necessary to increase the sampling effort, the time intervals throughout the day, and the use of different types of traps to establish which are the patterns of abundance, biomass, and species composition. Also, it is necessary an extra work in benthic copepod fauna sampling and identification, a group that remains poorly known both in Isla del Coco waters and along the coast of continental Costa Rica.

Ethical statement: authors declare that they all agree with this publication and made significant contributions; that there is no conflict of interest of any kind; and that we followed all pertinent ethical and legal procedures and requirements. All financial sources are fully and clearly stated in the acknowledgements section. A signed document has been filed in the journal archives.

\section{ACKNOWLEDGMENTS}

We thank Jeffrey Sibaja for his support in the statistical analysis; also, Jorge Cortés, Gerardo Umaña, Juan José Alvarado and Jeffrey Sibaja for the comments to this work, the Undersea Hunter Group and Isla del Coco National Park personnel for helping with the sampling. This work was supported by Consejo Nacional de Rectores (CONARE) through the grant 808-B0-654, and the grants 808-A7-520 from the French GEF and 808-B0-060.

\section{RESUMEN}

Variación nocturna del zooplancton en diferentes sustratos de un arrecife coralino de la Isla del Coco, Pacífico Oriental Tropical. Introducción: El zooplancton demersal en los arrecifes de coral diariamente realiza migraciones diarias durante la noche para evitar ser depredados, su abundancia y su biomasa aumentan durante la noche. Objetivos: Registrar la composición y la variación del zooplancton pelágico-demersal durante la noche y aumentar el conocimiento taxonómico de la fauna de copépodos bénticos sobre diferentes sustratos de un arrecifes de coral. Métodos: El zooplancton asociado a diferentes sustratos fue colectado usando trampas en forma de cono confeccionadas con una bolsa plástica y un copo colector de zooplancton de $100 \mu \mathrm{m}$, las trampas se ubicaron sobre cuatro tipos de sustratos en un arrecife de coral: (1) arena, (2) colonias pequeñas y (3) grandes de Porites lobata, y (4) coral vivo y muerto ubicadas entra 5 y $10 \mathrm{~m}$ de profundidad. El muestreo fue realizado durante 12 horas, las trampas fueron colocadas a las $1800 \mathrm{~h}$ y los copos colectores se cambiaron a las 2100, 0000 y 0600 h. Resultados: Los copépodos (adultos, copepoditos y nauplios) dominaron la composición y fueron más abundantes en todos los intervalos de tiempo y cada uno de los sustratos. Los copépodos pelágicos fueron más abundantes pero no más diversos que los bentónicos. Dentro de los copépodos bénticos recolectados, 20 nuevos registros fueron identificados para las aguas de la Isla del Coco y Costa Rica. Los cambios en la estructura de la comunidad del zooplancton de los arrecifes de coral se relacionaron con el intervalo tiempo de muestreo y no con el tipo de sustrato en que fue colocado la red. Conclusiones: La composición de la comunidad y la abundancia de zooplancton pelágico-demersal en los arrecifes de coral de Bahía Chatham fueron dominadas por copépodos, larvaceos y larvas de decápodos, similar a otros arrecifes de coral alrededor del mundo. El intervalo de tiempo con la mayor abundancia de organismos fue el de 0000 a $0600 \mathrm{~h}$, este pico de abundancia puede estar relacionado con la migración vertical.

Palabras clave: migración; demersal; trampas; abundance; Isla del Coco.

\section{REFERENCES}

Alldredge, A. L., \& King, J. M. (1977). Distribution, abundance, and substrate preferences of demersal reef zooplankton at Lizard Island Lagoon, Great Barrier Reef. Marine Biology, 41(4), 317-333.

Alldredge, A.L., \& King, J. M. (2009). Near-surface enrichment of zooplankton over a shallow back reef: implications for coral reef food webs. Coral Reefs, 28, 895-908.

Briggs, J. (1966). Oceanic islands, endemism, and marine paleotemperatures. Systematics Biology, 15, 153-163.

Castellanos, I., Hernández. R. M., Morales-Ramírez, A., \& Corrales, M. (2012). Appendicularians (Urochordata) and chaetognaths (Chaetognatha) of Isla del Coco National Park. Revista de Biología Tropical, 60(Supplement 3), 243-255.

Cortés, J. (2008). Historia de la investigación marina de la Isla del Coco, Costa Rica. Revista de Biología Tropical, 56(Supplement 2), 1-18.

Dean, H. K., Sibaja-Cordero, J. A., Cortes, J., Vargas, R., \& Kawauchi, G. Y. (2010). Sipunculans and Echiurans of Isla del Coco (Cocos Island), Costa Rica. Zootaxa, 2557(1), 60-68.

Dean, H. K., Sibaja-Cordero, J. A., \& Cortés, J. (2012). Polychaetes (Annelida: Polychaeta) of Cocos Island 
National Park, Pacific Costa Rica. Pacific Science, 66(3), 347-386.

Emery, A. R. (1968). Preliminary observations on coral reef plankton 1. Limnology and Oceanography, 13(2), 293-303.

Esquivel-Garrote, O., Suárez-Morales, E., \& MoralesRamírez, A. (2015). A new species of Pontella (Calanoida, Pontellidae) from an oceanic island of the eastern tropical Pacific. Proceedings of the Biological Society of Washington, 128(1), 137-151.

Gasca, R., \& Morales-Ramírez, A. (2012). Hyperiid amphipods (Crustacea: Peracarida) of the Parque Nacional Isla del Coco, Costa Rica, Eastern Tropical Pacific. Revista de Biología Tropical, 60(Supplement 3), 223-233.

Hamner, W. M., Jones, M. S., Carleton, J. H., Hauri, I. R., \& Williams, D. M. (1988). Zooplankton, planktivorous fish, and water currents on a windward reef face: Great Barrier Reef, Australia. Bulletin of Marine Science, 42(3), 459-479.

Heidelberg, K., Sebens, K., \& Purcell, J. (2004). Composition and sources of near reef zooplankton on a Jamaican forereef along with implications for coral feeding. Coral Reefs, 23(2), 263-276.

Heidelberg, K. B., O’neil, K. L., Bythell, J. C., \& Sebens, K. P. (2010). Vertical distribution and diel patterns of zooplankton abundance and biomass at Conch Reef, Florida Keys (USA). Journal of Plankton Research, 32(1), 75-91.

Jacoby, C. A., \& Greenwood, J. G. (1988). Spatial, temporal, and behavioral patterns in emergence of zooplankton in the lagoon of Heron Reef, Great Barrier Reef, Australia. Marine Biology, 97(3), 309-328.

Jiménez-Cueto, S. Suárez-Morales, E. \& Morales-Ramírez, A. (2012). Algunos poliquetos holoplanctónicos (Annelida: Polychaeta) del Parque Nacional Isla del Coco, Costa Rica, Revista de Biología Tropical, 60(Supplement 3), 207-222.

Kier, G., Kreft, H., Lee, T. M., Jetz, W., Ibisch, P. L., Nowicki, C., ... \& Barthlott, W. (2009). A global assessment of endemism and species richness across island and mainland regions. Proceedings of the National Academy of Sciences, 106(23), 9322-9327.

Lizano, O. (2008). Dinámica de aguas alrededor de la Isla del Coco, Costa Rica. Revista de Biología Tropical, 56(Supplement 2), 31-48.

Morales-Ramírez, Á., Suárez-Morales, E., Corrales-Ugalde, M., \& Esquivel-Garrote, O. (2014). Diversity of the free-living marine and freshwater Copepoda (Crustacea) in Costa Rica: a review. ZooKeys, 457(457), $15-33$.
Nakajima, R., Yoshida, T., Othman, B., \& Toda, T. (2008). Diel variation in abundance, biomass and size composition of zooplankton community over a coral-reef in Redang Island, Malaysia. Plankton and Benthos Research, 3(4), 216-226.

Nakajima, R., Yoshida, T., Othman, B., \& Toda, T. (2008). Diel variation of zooplankton in the tropical coralreef water of Tioman Island, Malaysia. Aquatic Ecology, 43(4), 965.

Ohlhorst, S. L. (1982). Diel migration patterns of demersal reef zooplankton. Journal of Experimental Marine Biology and Ecology, 60(1), 1-15.

Porter, J. W., \& Porter, K. G. (1977). Quantitative sampling of demersal plankton migrating from different coral reef substrates1. Limnology and Oceanography, 22(3), 553-556.

Sebens, K. P., Grace, S. P., Helmuth, B., Maney Jr, E. J., \& Miles, J. S. (1998). Water flow and prey capture by three scleractinian corals, Madracis mirabilis, Montastrea cavernosa and Porites porites, in a field enclosure. Marine Biology, 131(2), 347-360.

Sibaja-Cordero, J. A., Troncoso, J. S., \& Cortés, J. (2012). The lancelet Asymmetron lucayanum complex in Cocos Island National Park, Pacific Costa Rica. Pacific science, 66(4), 523-528.

Sibaja-Cordero, J. A., Troncoso, J. S., Cortés, J., Moreira, J., Vargas, J. A., \& Benavides-Varela, C. (2016). Biodiversity and density of subtidal benthos of an oceanic tropical island (a comparison within the Pacific Ocean). Journal of Sea Research, 115, 47-58.

Smith, J., Richter, C., Fabricius, K., \& Cornils, A. (2019). Neustonic copepods (Labidocera spp.) discovered living residentially in coral reefs. Marine Biodiversity, 49(1), 345-355.

Suárez-Morales, E., \& Gasca, R. (2012). A new Lepeophtheirus (Copepoda: Siphonostomatoida: Caligidae) from Isla del Coco National Park, Costa Rica, Eastern Tropical Pacific. Revista de Biología Tropical, 60(Supplement 3), 235-242.

Suarez-Morales, E., \& Morales-Ramírez, A. (2009). New species of Monstrilloida (Crustacea: Copepoda) from the Eastern Tropical Pacific. Journal of Natural History, 43(21-22), 1257-1271.

Yahel, R., Yahel, G., \& Genin, A. (2005a). Near- bottom depletion of zooplankton over coral reefs: I: diurnal dynamics and size distribution. Coral Reefs, 24(1), 75-85.

Yahel, R., Yahel, G., Berman, T., Jaffe, J. S., \& Genin, A. (2005b). Diel pattern with abrupt crepuscular changes of zooplankton over a coral reef. Limnology and Oceanography, 50(3), 930-944. 